\title{
Ocena rządowego projektu nowelizacji ustawy o podatku od towarów i usług oraz ustawy - Ordynacja podatkowa ${ }^{1}$
}

Assessment of the governmental Bill on Amendment of the VAT Act and the Tax Ordinance Act: In the author's opinion the proposed change in the way of identifying goods and services for VAT purposes, taking as a point of reference the coherence with the EU law, should be assessed positively. The consequence of these changes will be a reduction in the tax rate regarding books and electronic journals. However, raising the tax rate for, among others, certain fruit drinks may have negative economic, social and political consequences. According to the author, increasing VAT rates should be justified for both economic and social reasons.

Keywords: tax ordinance act, tax, bill, VAT

Słowa kluczowe: ordynacja podatkowa, podatek, projekt ustawy, VAT

Doktor nauk prawnych, ekspert ds. finansów publicznych BAS - jacek.kulicki@sejm.gov.pl - https://orcid.org/0000-0003-2631-6428

\section{Zakres przedmiotowy ustawy}

Projektowana ustawa wprowadza zmiany w ustawach: z 11 marca 2011 r. o podatku od towarów i usług (t.j. Dz.U. 2018, poz. 2174, ze zm.; dalej: u.p.t.u.) oraz z 29 sierpnia 1997 r. - Ordynacja podatkowa (t.j. Dz.U. 2018, r. poz. 800, ze zm.; dalej: o.p.).

Nowelizacja ustawy o podatku od towarów i usług dotyczy:

- zmiany sposobu identyfikowania towarów i usług dla celów podatku VAT, tj. zastąpienie w przypadku towarów Polskiej Klasyfikacji Wyrobów i Usług

Ocena skutków regulacji zawartych w rządowym projekcie ustawy o zmianie ustawy o podatku od towarów i usług oraz ustawy - Ordynacja podatkowa (druk nr 3255) sporządzona 29 marca 2019 r. na zlecenie zastępcy Szefa Kancelarii Sejmu; BAS-WASiE 451/19. 
z 2008 r. (PKWiU 2008)² Nomenklaturą Scaloną (CN)³, zaś w przypadku usług PKWiU 2008 Polską Klasyfikacją Towarów i Usług z 2015 r. (PKWiU 2015) $)^{4}$

- wprowadzenia tzw. nowej matrycy stawek podatku VAT, której założeniem jest - jak wynika z uzasadnienia projektu rządowego (s. 3-4) - objęcie taką samą stawką podatku całych („w miarę możliwości i przy racjonalności systemu”) działów CN, co oznacza zarówno obniżenie, jak i podwyższenie (w niektórych przypadkach) stawek podatku od towarów i usług dla towarów. Obniżeniu ulegają m.in. stawki podatku na owoce tropikalne i cytrusowe (z 8\% do $5 \%$ ), pieczywo oraz wyroby ciastkarskie (z 8\% lub 23\% - w zależności od rodzaju - do 5\%), dietetyczne środki spożywcze specjalnego przeznaczenia medycznego (z 8\% do 5\%), książki w formie elektronicznej (z 23\% do 5\%), artykuły higieniczne - podpaski, tampony, pieluchy (z 8\% do 5\%), gazety, dzienniki, czasopisma, również w formie elektronicznej (z 23\% do 8\%). Podwyższeniu ulegają natomiast stawki m.in. na niektóre przyprawy nieprzetworzone (z 5\% do $8 \%$ ), niektóre napoje z owoców i warzyw (z 5\% do 23\%), lód używany do celów spożywczych (z 8\% do 23\%), czasopisma specjalistyczne (z 5\% do 8\%),

- systemu ryczałtowego dla rolników,

- wprowadzenia instytucji wiążącej informacji stawkowej (WIS),

- systemu odwróconego obciążenia i instytucji solidarnej odpowiedzialności.

Zmiany w ordynacji podatkowej są konsekwencją wprowadzenia do ustawy o podatku od towarów i usług instytucji wiążącej informacji stawkowej. Odnoszą się one do regulacji dotyczących właściwości Szefa Krajowej Administracji Skarbowej (KAS) oraz dyrektora Krajowej Informacji Skarbowej (KIS), a także zakresu interpretacji indywidualnych przepisów prawa podatkowego, z których wyłączono regulacje objęte wiążącymi informacjami stawkowymi.

Większość przepisów projektu zmieniających ustawę o podatku od towarów i usług i ordynację podatkową ma wejść w życie z dniem 1 czerwca 2019 r., część natomiast $\mathrm{z}$ dniem 1 stycznia 2020 r. (art. 8 projektu).

2 Rozporządzenie Rady Ministrów z 29 października 2008 r. w sprawie Polskiej Klasyfikacji Wyrobów i Usług (PKWiU), Dz.U. nr 207, poz. 1293, ze zm.

3 Zob. rozporządzenie Rady (EWG) nr 2658/87 z 23 lipca 1987 r. w sprawie nomenklatury taryfowej i statystycznej oraz w sprawie Wspólnej Taryfy Celnej (Dz.Urz. WE L 256 z 7 września 1987, s. 1, ze zm.; Dz.Urz. UE, polskie wydanie specjalne, rozdz. 2, t. 2, s. 382, ze zm.), rozporządzenie Rady Ministrów z 24 grudnia 2010 r. w sprawie Nomenklatury Scalonej (Dz.U. nr 258, poz. 1749) oraz rozporządzenie wykonawcze Komisji (UE) 2018/1602 z 11 października 2018 r. zmieniające załącznik I do rozporządzenia Rady (EWG) nr 2658/87 w sprawie nomenklatury taryfowej i statystycznej oraz w sprawie Wspólnej Taryfy Celnej (Dz.Urz. UE L 273 z 31 października 2018 r., s. 1).

4 Rozporządzenie Rady Ministrów z 4 września 2015 r. w sprawie Polskiej Klasyfikacji Wyrobów i Usług (PKWiU), Dz.U. poz. 1676, ze zm. 
W projekcie przewidziano również regulacje przejściowe, które dotyczą zarówno stawek podatku od towarów i usług, jak i wiążącej informacji stawkowej. Odnoszą się one do:

- przepisów regulujących wysokość stawek podatkowych, które w brzmieniu wynikającym z projektowanej nowelizacji będą stosowane od 1 stycznia 2020 r. (art. 3 ust. 1 i 2 projektu). Wyjątek dotyczy stawek na książki, mapy, nuty, czasopisma (nowe stawki mają być stosowane od 1 czerwca 2019 r. art. 4 ust. 1 i 2 projektu),

- wiążącej informacji stawkowej. Przepisy przejściowe regulują zasady wydawania WIS przed 1 stycznia 2020 r. (art. 3 ust. 3 projektu) oraz związanie organów podatkowych decyzjami WIS wydanymi przed 1 stycznia $2020 \mathrm{r}$. (art. 3 ust. 4 i 5 projektu, a w przypadku WIS dotyczących stawek na książki, gazety, czasopisma, mapy - art. 4 ust. 3 i 4 projektu).

W projekcie uregulowano również maksymalny limit wydatków budżetu państwa przeznaczonych na realizację zadań w zakresie wydawania wiążących informacji stawkowych (art. 7 projektu).

\section{Podmioty, na które oddziałuje akt}

Projekt dotyczy:

- bezpośrednio:

a) podatników podatku od towarów i usług - ok. 1,7 mln podmiotów ${ }^{5}$,

b) dyrektora Krajowej Informacji Skarbowej, który będzie organem właściwym w sprawach WIS w I i II instancji,

c) Szefa Krajowej Administracji Skarbowej, który będzie organem właściwym do zmiany lub uchylenia WIS z urzędu,

- pośrednio:

a) organów podatkowych i obsługujących ich izb administracji skarbowej, urzędów celno-skarbowych, które będą związane wiążącymi informacjami stawkowymi,

b) sądów administracyjnych (Naczelnego Sądu Administracyjnego i wojewódzkich sądów administracyjnych), które będą rozpatrywały skargi na wiążące informacje stawkowe,

c) kontrahentów podatników VAT,

d) nabywców detalicznych towarów i usług.

5 Według danych Ministerstwa Finansów na koniec 2017 r. liczba podatników VAT czynnych obowiązanych do składania deklaracji dla podatku od towarów i usług wynosiła 1653110 podatników 


\section{Celowość wprowadzenia aktu}

Jak wynika z uzasadnienia rządowego projektu ustawy, nowelizacja ustawy o podatku od towarów i usług i ordynacji podatkowej ma na celu przede wszystkim zmianę nieefektywnego i krytykowanego za skomplikowanie systemu podatku VAT w zakresie określania stawek tego podatku. Nowy system ma być oparty na trzech filarach: prostoty, przejrzystości i przyjazności stosowania. Ma również gwarantować ochronę podatnikom w zakresie stosowania przez nich stawek podatku od towarów i usług poprzez instytucję WIS.

Wnioskodawcy w uzasadnieniu projektu wskazali, że nowy system: $z$ decydowanie przyczyni się do poprawy warunków prowadzenia działalności gospodarczej podatników, $w$ tym mikroprzedsiębiorców oraz małych $i$ średnich przedsiębiorstw oraz ułatwi korzystanie z przepisów prawa podatkowego i prawidłowe ich stosowanie w praktyce gospodarczej (np. skróci czas i koszty wykonywania określonych czynności administracyjnych), a także zapewni - poprzez wprowadzenie instytucji wiążącej informacji stawkowej - stabilność w obszarze stosowania prawa podatkowego, co również przełoży się na ograniczenie kosztów związanych z prowadzeniem działalności gospodarczej.

W „Ocenie skutków regulacji” załączonej do projektu wskazano, że proponowane zmiany:

- spowodują ubytek dochodów budżetu państwa z tytułu podatku od towarów i usług do 2029 r. w kwocie $3380 \mathrm{mln}$ zł, przy czym w roku wejścia ustawy w życie (2019 r.) ubytek ten wyniesie 109 mln zl, w 2020 r. - 319 mln zl, zaś w każdym z następnych lat (2021-2029) - po 328 mln zł rocznie,

- wiązać się będą z wydatkami budżetu państwa do 2029 r. na pokrycie kosztów administracyjnych (wynagrodzenia pracowników, organizacja stanowisk pracy) w kwocie 288,9 mln zł, przy czym w roku wejścia w życie ustawy (2019 r.) wydatki te wyniosą $15,1 \mathrm{mln}$ zł,

- wpłyną pozytywnie na konkurencyjność gospodarki i przedsiębiorczość oraz rodzinę, obywateli i gospodarstwa domowe, przynosząc oszczędności w okresie pierwszych jedenastu lat (od roku wejścia w życie ustawy):

a) dla dużych przedsiębiorstw oraz sektora mikro, małych i średnich przedsiębiorstw - $1196 \mathrm{mln}$ zł (w roku 2019 - 39 mln, w 2020 r. - 113 mln, zaś w każdym - po $116 \mathrm{mln}$ zł),

b) dla rodziny, obywateli i gospodarstw domowych $-2184 \mathrm{mln}$ zł (w roku 2019 - 70 mln zł, w 2020 r. - 206 mln zł, zaś w każdym następnych - po $212 \mathrm{mln} \mathrm{zl})$.

Wnioskodawcy podkreślają, że proponowane zmiany „nie mają celu fiskalnego", a ich intencją jest: maksymalne uproszczenie systemu $i$ samych przepisów podatkowych, a co za tym idzie: zasadniczo pozostana neutralne dla konsumentów (gospodarstw domowych, w tym również osób starszych i niepetnosprawnych). 
Utworzenie: etatów w organach administracji podatkowej w związku $z$ wprowadzeniem systemu WIS powinno pozytywnie wpłynąć na dochody gospodarstw domowych.

\section{Planowane środki (narzędzia i działania) realizacji celów}

Środkiem do realizacji zakładanego celu - zmiany nieefektywnego systemu podatku VAT w zakresie stawek tego podatku, jego uproszczenia - jest nowelizacja ustawy o podatku od towarów i usług i zmiana sposobu identyfikowania towarów i usług dla potrzeb podatku od towarów i usług: zastąpienie PKWiU 2008 Nomenklaturą Scaloną (w przypadku towarów) i PKWiU 2015 (w przypadku usług). Pozostałe zmiany w ustawie o podatku od towarów i usług i ordynacji podatkowej są $\mathrm{w}$ istocie pochodną zmian wynikających z zastąpienia dotychczasowej klasyfikacji statystycznej (PKWiU 2008) nowymi klasyfikacjami statystycznymi (PKWiU 2015 i CN).

\section{Ocena kosztów i korzyści}

Projektowana zmiana ustawy o podatku od towarów i usług wywiera skutki zarówno na płaszczyźnie prawnej, gospodarczej, społecznej i politycznej, jak i finansowej (budżetu państwa).

\section{Ocena skutków prawnych}

Proponowaną w projekcie zmianę sposobu identyfikowania towarów i usług dla potrzeb podatku od towarów i usług (dalej również podatek VAT) należy ocenić pozytywnie, biorąc za punkt odniesienia spójność z prawem UE.

W obecnym stanie prawnym podstawę identyfikowania towarów dla potrzeb podatku VAT stanowi PKWiU 2008, zaś klasyfikacja CN - dla celów poboru podatku w imporcie (art. 41 ust. 15 u.p.t.u. ${ }^{6}$ ). Skutkiem takiego stanu rzeczy jest komplikacja systemu oraz możliwość różnego sposobu traktowania towarów w obrocie krajowym i importowanych. Stosowanie klasyfikacji statystycznych w podatku od towarów i usług jest niezbędne przede wszystkim z uwagi na rozbudowane stawki tego podatku. Podatek VAT należy do podatków zharmonizowanych w Unii Europejskiej (UE) ${ }^{7}$. Zgodnie z art. 98 ust. 1 dyrektywy

6 Zob. rozporządzenie Ministra Finansów z 22 grudnia 2011 r. w sprawie wykazu towarów do celów poboru podatku od towarów i usług w imporcie, Dz.U. 2019, poz. 132.

7 Zob. art. 113 Traktatu o funkcjonowaniu Unii Europejskiej (TFUE) oraz dyrektywę Rady 2006/112/WE z 28 listopada 2006 r. w sprawie wspólnego systemu podatku od wartości dodanej, Dz.Urz. UE L 347 z 11 grudnia 2006 r., s. 1, ze zm. 
VAT państwa członkowskie mogą stosować jedną lub dwie stawki obniżone, przy czym stawki te mogą być stosowane wyłącznie do dostaw towarów i świadczenia usług, których kategorie są określone w załączniku III. Stawki obniżone nie mogą być jednak stosowane do usług świadczonych drogą elektroniczną, z wyjątkiem książek, dzienników, periodyków ${ }^{8}$. Zgodnie z art. 98 ust. 3 dyrektywy VAT przy stosowaniu stawek obniżonych państwa członkowskie mogą stosować nomenklaturę scaloną, aby precyzyjnie określić zakres danej kategorii towarów objętych stawką ulgową. Jak zauważa się w literaturze przedmiotu, załącznik III dyrektywy VAT: opiera się wyłącznie na opisie towarów, bez żadnych odwołań do klasyfikacji, w tym statystycznych. Z kolei załaczniki do ustawy o VAT dla towarów opodatkowanych stawkami niższymi niż 23\% w większości przypadków odwołuja się do symboli statystycznych, co może prowadzić do niezgodności z dyrektywa. Szerszy zakres stanowitby niewątpliwie naruszenie przepisów dyrektywy VAT. $Z$ kolei węższy zakres co do zasady jest możliwy na gruncie przepisów unijnych, z tym że niedopuszczalne jest stosowanie różnych stawek dla towarów podobnych, które pozostają ze soba $w$ relacji konkurencyjnej ${ }^{9}$.

Projekt - wprowadzając jako zasadę identyfikację towarów dla celów ustawy o podatku od towarów i usług na podstawie Nomenklatury Scalonej - eliminuje możliwość różnego sposobu traktowania towarów w obrocie krajowym i importowanych oraz niebezpieczeństwo niezgodności stawek preferencyjnych z dyrektywą VAT.

Zmiana sposobu identyfikowania towarów i usług dla celów podatku VAT, choć znacznie ogranicza liczbę pozycji wykazu towarów i usług objętych stawkami obniżonymi (z obowiązujących 150 do 74 w załączniku nr 3 do ustawy o podatku od towarów i usług ${ }^{10}$ i z 35 do 24 w załączniku nr 10 do ustawy o podatku od towarów i usług ${ }^{11}$ ), nie stanowi istotnego uproszczenia systemu podatku od towarów i usług. W dalszym ciągu będziemy mieli do czynienia z systemem opartym na stosunkowo wysokiej stawce podstawowej (obecnie 23\%, art. 146aa u.p.t.u.) oraz rozbudowaną strukturę stawek obniżonych, co niewątpliwie wpływa negatywnie na:

- pewność prawa (pewność taką ma przynieść dopiero system WIS),

- koszty poboru podatku, zob. proponowany system WIS, będący uzupełnieniem już istniejących: interpretacji podatkowych (ogólnej i indywidualnej), objaśnień podatkowych (urzędowych ogólnych wyjaśnień przepisów prawa

8 Zob. dyrektywę Rady (UE) 2018/1713 z 6 listopada 2018 r. zmieniającą dyrektywę 2006/112/WE w odniesieniu do stawek podatku od wartości dodanej stosowanego do książek, gazet i czasopism, Dz.Urz. UE L 286 z 14 listopada 2018 r., s. 20.

9 Zob. P. Marchlewski [w:] Dyrektywa VAT. Polska perspektywa, red. R. Namysłowki, D. Prokop, Warszawa 2012, s. 212-213.

10 Załącznik nr 3 zawiera wykaz towarów i usług opodatkowanych stawką 7\% (obecnie $8 \%)$.

11 Załącznik nr 10 zawiera wykaz towarów opodatkowanych stawką 5\%. 
podatkowego dotyczących stosowania tych przepisów, art. 14a-14s o.p., wiążących informacji akcyzowych ${ }^{12}$, opinii zabezpieczających, art. 119w-119zf o.p., porozumień w sprawach ustalania cen transakcyjnych, art. 20a-20r o.p.), - koszty przestrzegania przepisów przez podatników.

W kontekście uproszczenia podatku VAT nie można nie zauważyć również, że komplikacja tego podatku związana jest w pierwszej kolejności z ograniczeniami, jakie ustawodawca wprowadza w zakresie możliwości odliczenia podatku naliczonego (zapłaconego w cenie nabycia towaru lub usługi), co jest przedmiotem troski ustawodawcy przede wszystkim w związku z uszczelnianiem systemu podatkowego.

Reasumując, trzeba stwierdzić, że zmianę systemu identyfikowania towarów i usług dla potrzeb podatku VAT (zastąpienie PKWiU 2008 Nomenklaturą Scaloną i w odniesieniu do usług PKWiU 2015) należy ocenić pozytywnie, aczkolwiek nie można przeceniać wpływu tej zmiany na przejrzystość i spójność systemu podatku od towarów i usług, które w istocie przesądzają o pewności prawa, zarówno w odniesieniu do podatników, jak i organów podatkowych. Jak wynika z uzasadnienia rządowego projektu, pewność taką, po zmianie sposobu identyfikowania towarów i usług dla celów VAT, ma dać WIS. Oznacza to, że sami projektodawcy nie są pewni spójności i przejrzystości projektowanych zmian i prawnych konsekwencji zastąpienia PKWiU 2008 Nomenklaturą Scaloną (w odniesieniu do towarów) i PKWiU 2015 (w odniesieniu do usług). W uzasadnieniu projektu wskazano jedynie niektóre ze zmian stawek podatku od towarów i usług. Dla zobrazowania wszystkich konsekwencji prawnych projektowanej regulacji konieczne byłoby powiązanie dotychczasowej tabeli (matrycy) stawek preferencyjnych z nową tabelą (matrycą) stawek obniżonych, czego brak w uzasadnieniu. Nie bez znaczenia dla konsekwencji prawnych pozostaje również zakres zgłoszonych uwag do projektu w trakcie konsultacji publicznych, z których tylko niewielka część została uwzględniona lub częściowo uwzględniona przez wnioskodawcę.

\section{Ocena skutków gospodarczych, społecznych i politycznych}

Projekt $\mathrm{w}$ zakresie sposobu identyfikowania towarów i usług dla potrzeb podatku VAT nie ogranicza się jedynie do przełożenia obecnych wykazów towarów i usług objętych stawkami obniżonymi, opartych na PKWiU 2008, na wykazy oparte na CN (w odniesieniu do towarów) i PKWiU 2015 (w odniesieniu do usług). Wprowadza bowiem korekty stawek VAT, m.in. na:

- owoce tropikalne i cytrusowe, niektóre orzechy (pistacjowe, kokosowe, migdały) - obniżenie stawki z 8\% do 5\%,

12 Zob. art. 7d-7k ustawy z 6 grudnia 2008 r. o podatku akcyzowym, t.j. Dz.U. 2018, poz. 1114, ze zm. 
- pieczywo każdego rodzaju, włącznie z ciastkami - ujednolicenie stawki na poziomie 5\%, w tym obniżenie z 23\% lub $8 \%$ - w zależności od rodzaju pieczywa,

- zupy, buliony, żywność homogenizowaną i dietetyczną, w tym dietetyczne środki spożywcze specjalnego przeznaczenia medycznego - obniżenie stawki z $8 \%$ do $5 \%$,

- musztardę, słodką paprykę, niektóre przyprawy przetworzone (np. pieprz, gałka muszkatołowa, tymianek) - obniżenie stawki z 23\% do 8\%,

- książki (wszelkiego rodzaju), drukowane i na innych nośnikach, w tym w formie elektronicznej (e-booki) - ujednolicenie stawki na poziomie 5\% (w tym obniżenie dla wydawnictw elektronicznych z 23\% do 5\%),

- produkty dla niemowląt i dzieci (żywność, pieluszki, foteliki samochodowe) obniżenie stawki z $8 \%$ do $5 \%$,

- artykuły higieniczne (podpaski, tampony, pieluchy) - obniżenie stawki z 8\% do $5 \%$,

- gazety, dzienniki, czasopisma drukowane i na innych nośnikach, w tym w formie elektronicznej (e-prasa) - ujednolicenie stawki na poziomie 8\% (wyjątek czasopisma regionalne i lokalne - stawka 5\%),

- niektóre przyprawy nieprzetworzone (np. gałka muszkatołowa, kwiat muszkatołowy, kmin, szafran, kurkuma) - podwyższenie stawki z 5\% na 8\%,

- napoje z owoców i warzyw inne niż soki i nektary z owoców i napoje warzywne zawierające co najmniej 50\% wsadu warzywnego w składzie surowcowym (które pozostaną objęte stawką 5\%) - podwyższenie stawki z 5\% na 23\%,

- homary i ośmiornice oraz inne skorupiaki, mięczaki i bezkręgowce wodne (m.in. kraby, langusty, krewetki, ostrygi, małże, ślimaki) oraz przetwory $\mathrm{z}$ nich, kawior oraz namiastki kawioru, jak również sprzedawane w różnego rodzaju placówkach gastronomicznych posiłki, których składnikiem są wymienione produkty - podwyższenie stawki z 5\% na 23\%,

- lód używany do celów spożywczych i innych celów chłodniczych - podwyższenie stawki z $8 \%$ na $23 \%$.

Jak wynika $\mathrm{z}$ uzasadnienia projektu rządowego: planowane zmiany nie maja celu fiskalnego, natomiast maja uprościć system i zdecydowanie ograniczyć niekonsekwencje w stosowaniu stawek VAT - uporządkowane stawki obniżone będq miały budżetowo neutralny charakter, a uproszczenie stawek powinno dać impuls prorozwojowy (uzasadnienie, s. 6).

Oczywiście, po rozpatrzeniu proponowanych zmian dotyczących stawek podatku od towarów i usług całościowo łatwo stwierdzić, że wniosek o braku fiskalnego celu projektowanej regulacji jest jak najbardziej uzasadniony (wprowadzenie tzw. nowej matrycy stawek VAT ma obniżyć dochody budżetu państwa do 2029 r. w kwocie $3380 \mathrm{mln}$ zł, przy czym w roku wejścia ustawy w życie o $109 \mathrm{mln}$ zł). Racjonalne wydaje się również stwierdzenie, że: wobec podejścia zakładające- 
go ujednolicenie opodatkowania całych grup towarowych, jak również generalnego obniżania stawek podatku dla produktów niezbędnych do zaspokojenia podstawowych potrzeb człowieka, koniecznym było punktowe podwyższenie stawek podatku dla niektórych towarów (uzasadnienie, s. 6). Co istotne, podwyżki te uzasadniane są koniecznością ujednolicenia całych grup towarowych. I tak, np.:

- podniesienie stawki z 5\% do 8\% na niektóre przyprawy nieprzetworzone (np. gałka muszkatołowa, kwiat muszkatołowy, kmin, szafran, kurkuma) jest "efektem ujednolicenia stawek VAT dla przypraw”,

- podniesienie stawki z 5\% na $23 \%$ na napoje z owoców i warzyw inne niż soki i nektary z owoców i napoje warzywne zawierające co najmniej 50\% wsadu warzywnego w składzie surowcowym (które pozostaną objęte stawką 5\%) „związane jest z ujednoliceniem stawki dla większości napojów - kawa, herbata, woda butelkowana",

- podniesienie stawki na czasopisma specjalistyczne z 5\% do 8\% jest efektem ujednolicenia stawki na wszystkie gazety i czasopisma, z wyjątkiem czasopism regionalnych i lokalnych (w tym przypadku ma pozostać stawka 5\%).

Z punktu widzenia gospodarki państwa na szczególną uwagę zasługuje podniesienie stawki VAT na napoje z owoców i warzyw z 5\% do 23\%. Zmiana ta (podwyższenie stawki) uzasadniana jest w projekcie ustawy „ujednoliceniem stawki dla większości napojów - kawa, herbata, woda butelkowana" (uzasadnienie, s. 7). Uzasadnienie takie jest racjonalne $\mathrm{z}$ „technicznego” punktu widzenia. Jeżeli jednak weźmiemy pod uwagę rynek przetwórstwa owocowo-warzywnego w Polsce (producentów owoców i warzyw, producentów soków, nektarów i napojów owocowych, strukturę upraw owoców w Polsce ${ }^{13}$, miejsce Polski w produkcji owoców w $\mathrm{UE}^{14}$, obecne bariery rynku owoców i warzyw ${ }^{15}$, strukturę przetwór-

13 Wśród owoców innych niż jagodowe ponad 70\% upraw stanowią jabłka, 12\% wiśnie, $5 \%$ śliwki, $4 \%$ czereśnie, $4 \%$ gruszki, zaś $2 \%$ brzoskwinie i morele. Wśród owoców jagodowych - 38\% truskawka, $26 \%$ porzeczka czarna, $20 \%$ malina, $6 \%$ porzeczka kolorowa, 5\% borówka, 3\% aronia, http://uniaowocowa.pl/images/PREZENTACJA_dot._VAT.pdf [dostęp 26 marca 2019 r.]. Zob. też GUS, Produkcja upraw rolnych i ogrodniczych w 2017 r., Warszawa 2018, tablice 67-77.

14 Polska zajmuje pierwsze miejsce w UE w produkcji jabłek, wiśni, malin, porzeczek, zaś drugie miejsce po Hiszpanii w produkcji truskawek, http://uniaowocowa.pl/images/PREZENTACJA_dot._VAT.pdf [dostęp 26 marca 2019 r.].

15 Wśród barier wymienia się najczęściej: problem ze sprzedażą owoców, w tym jabłek, spowodowany nadprodukcją, rosnącą konkurencję rynków wschodnich (Chiny, Iran, Turcja, Ukraina, Mołdawia), problemy z eksportem (embargo rosyjskie, ograniczone możliwości eksportu do Azji), stagnację na rynku soków, nektarów i napojów owocowych lub warzywnych wynikającą z wyboru przez konsumentów napojów gazowanych, piwa bezalkoholowego i wody, niską konsumpcję owoców i warzyw oraz przetworów w UE (w przypadku owoców i przetworów owocowych: w Polsce - nieco 
stwa jabłek w Polsce ${ }^{16}$, strukturę rynku soków, nektarów i napojów ${ }^{17}$, konsumpcję per capita napojów w Polsce ${ }^{18}$ ), to decyzję o podwyższeniu stawek VAT na część napojów z soków i warzyw należy uznać za niezrozumiałą z gospodarczego punktu widzenia.

Konsekwencją projektowanej zmiany może być ograniczenie zapotrzebowania polskiego przemysłu przetwórstwa owocowo-warzywnego na owoce i warzywa $\mathrm{z}$ polskich upraw, szacowane na $75 \%{ }^{19}$, a w konsekwencji zmiana struktury spożycia napojów bezalkoholowych, pogłębienie się trudności branży owocowo-warzywnej (producentów owoców i przetwórców), prowadzące do upadku wielu gospodarstw ogrodniczych i zakładów przetwórczych, a także pogłębienia bezrobocia na rynkach lokalnych.

Reasumując, należy stwierdzić, że punktem odniesienia dla określania stawek podatkowych nie mogą być klasyfikacje statystyczne. Uproszczenie przepisów dotyczących stawek podatkowych - w tym przypadku stawek VAT - nie może prowadzić do podwyższenia tych stawek, o ile inne względy (gospodarcze, społeczne) nie przemawiają za taką zmianą. Z uzasadnienia projektu rządowego wynika, że tzw. prostota i przejrzystość systemu (uzasadnienie, s. 4) miała pierwszoplanowe znaczenie dla zdefiniowania „nowej matrycy stawek podatku od towarów i usług", a więc sporządzenia wykazu towarów i usług objętych preferencyjnymi (obniżonymi) stawkami. Pod uwagę nie były brane względy gospodarcze i społeczne (uzasadnienie rządowego projektu nie wspomina o nich), lecz

ponad $50 \mathrm{~kg}$ rocznie na osobę, zaś w UE - $100 \mathrm{~kg}$, w przypadku warzyw i przetworów warzywnych - w Polsce ok. $125 \mathrm{~kg}$ na osobę rocznie, zaś w UE ok. $120 \mathrm{~kg}$ ), http:// uniaowocowa.pl/images/PREZENTACJA_dot._VAT.pdf [dostęp 26 marca 2019 r.].

16 87,7\% (2050 tys. ton) stanowi produkcja zagęszczonego soku jabłkowego (koncentratu) wykorzystywanego do produkcji soków, nektarów i napojów. Pozostałą część stanowią soki NFC (nie z koncentratu), cydr, moszcze, jabłka mrożone, musy i przeciery, susze i liofilizaty, http://uniaowocowa.pl/images/PREZENTACJA_dot._VAT. pdf [dostęp 26 marca 2019 r.].

17 Największa część rynku napojów bezalkoholowych w Polsce przypada na wodę mineralną (3 468739 tys. 1), zaś soki, nektary i napoje stanowią trzykrotnie mniejszą część rynku (1 164745 tys. 1). W dalszej kolejności: napoje gazowane cola (1 060549 tys. 1), napoje gazowane owocowe (584 680 tys. 1), woda aromatyzowana (439 889 tys. 1), herbaty mrożone (177 303 tys. 1) i energetyki (150 793 tys. 1), http://uniaowocowa.pl/ images/PREZENTACJA_dot._VAT.pdf [dostęp 26 marca 2019 r.]. Zob. też D. Paszko, J. Pawlak, K. Woźniak, Rynek soków i nektarów owocowych w Polsce, https://docplayer. $\mathrm{pl} / 21823486-$ Rynek-sokow-i-nektarow-owocowych-w-polsce.html [dostęp 26 marca 2019 r.].

18 Napoje gazowane - 51,21 l, soki - 15,45 l, nektary - 7,2 l, napoje niegazowane - 14,67 l (dane za 2017 r.). Jedynie w Polsce istnieje duży udział spożycia napojów z owoców i warzyw o minimum $20 \%$ wsadu soku/przecieru, http://uniaowocowa.pl/images/ PREZENTACJA_dot._VAT.pdf [dostęp 26 marca 2019 r.].

19 Ibidem. 
przede wszystkim możliwość zbilansowania skutków budżetowych obniżenia części stawek VAT podniesieniem stawek na niektóre inne towary i usługi. Argumenty zdrowotne (wysoki poziom zawartości cukru w napojach owocowych) pojawiają się dopiero $\mathrm{w}$ dyskusji sejmowej $\mathrm{i}$ to $\mathrm{w}$ odpowiedzi na wątpliwości posłów o zasadność podwyżki stawki VAT na napoje owocowe ${ }^{20}$. Podobnie, jak zapewnienie o braku ryzyka negatywnych skutków przyjętych rozwiązań dla branży przetwórstwa owocowo-warzywnego.

Niewątpliwie argument prozdrowotny (zawartość cukru) należy uznać za istotny dla kształtowania stawek podatku VAT (podatki pełnią nie tylko funkcję fiskalną, ale mogą być nakładane dla osiągnięcia innych celów polityki rządu ${ }^{21}$ ), jednak nie może on być traktowany wybiórczo (zob. obniżenie stawki podatku na chipsy). Polityka państwa nie powinna w tym zakresie budzić wątpliwości i jednakowo traktować wszystkie produkty szkodliwe dla zdrowia ludzi. W tym wypadku najwłaściwsze byłoby wprowadzenie na towary (wyroby, produkty) uznane za szkodliwe dla zdrowia ludzi (np. z dużą zawartością cukru) specjalnej opłaty, które nie miałaby celu fiskalnego, a prozdrowotny (zniechęcałaby do produkcji i sprzedaży określonych towarów zagrażających zdrowiu ludzkiemu); powinna przy tym stanowić przychód funduszu celowego, którego środki przeznaczone byłyby na walkę z konsekwencjami niezdrowego żywienia.

Kształtowanie stawek podatkowych ma, obok aspektu prawnego, fiskalnego i gospodarczego, również aspekt społeczny i polityczny. Oznacza to, że decyzja o podwyższeniu lub obniżeniu stawki podatkowej musi uwzględniać zarówno prawną (spójność i przejrzystość systemu), fiskalną (wpływ na dochody budżetowe) i gospodarczą (wpływ na przedsiębiorców) stronę, lecz również brać pod uwagę odbiór społeczny proponowanych regulacji oraz uwarunkowania polityczne.

Projektowanej zmiany zakresu przedmiotowego obniżonych stawek podatku od towarów i usług nie można więc rozpatrywać w oderwaniu od nowych propozycji większości parlamentarnej dotyczącej rozszerzenia zakresu podmiotowego programu 500+, dodatkowego świadczenia emerytalnego (tzw. trzynastej emerytury), zwiększenia kosztów uzyskania przychodów dla pracowników, zwolnienia z podatku dochodowego dochodów z pracy osób do 26. roku życia. W związku z tym podwyższenie stawek VAT na niektóre towary (m.in. napoje owocowe) może być odebrane przez społeczeństwo jedynie jako działanie profiskalne, mające na celu zwiększenie dochodów budżetu państwa, aby zmniejszyć deficyt budżetowy będący następstwem realizacji m.in. projektów socjalnych.

20 Zob. Sprawozdanie stenograficzne z 78. posiedzenia Sejmu Rzeczypospolitej Polskiej w dniu 13 marca 2019 r. (pierwszy dzień posiedzenia), s. 115-127, www.orka2.sejm. gov.pl/StenoInter8.nsf/0/C4AC0EBBED0AB979C12583BD000C6500/\%24File/78 _a_ksiazka.pdf [dostęp 26 marca 2019 r.].

21 A. Gomułowicz, D. Mączyński, Podatki i prawo podatkowe, Warszawa 2016, s. 348359. 
Rozpatrując projektowane zmiany ustawy o podatku od towarów i usług, przede wszystkim w zakresie podwyższenia stawek VAT, nie można nie zauważyć, że przedstawienie ich w roku wyborczym może przesłonić:

- skalę obniżek stawek podatku od towarów i usług,

- rozszerzenie zakresu zryczałtowanego systemu podatku VAT od rolników,

- zmiany dotyczące odwrotnego obciążenia i instytucji solidarnej odpowiedzialności,

- wprowadzenie systemu WIS.

\section{Ocena skutków finansowych}

W „Ocenie skutków regulacji” załączonej do projektu wskazano, że proponowane zmiany pociągną za sobą trzy rodzaje następstw.

- Spowodują ubytek dochodów budżetu państwa z tytułu podatku od towarów i usług do 2029 r. w kwocie $3380 \mathrm{mln}$ zł, przy czym w roku wejścia ustawy w życie (2019 r.) ubytek ten wyniesie 109 mln zł, w 2020 r. - 319 mln zł, zaś w każdym z następnych lat (2021-2029) - po $328 \mathrm{mln}$ zł rocznie.

- Wiązać się będą z wydatkami budżetu państwa do 2029 r. na pokrycie kosztów administracyjnych (wynagrodzenia pracowników, organizacja stanowisk pracy w związku z wprowadzeniem WIS) w kwocie 288,9 mln zł, przy czym w roku wejścia w życie ustawy (2019 r.) wydatki te wyniosą 15,1 mln zł.

- Wpłyną pozytywnie na konkurencyjność gospodarki i przedsiębiorczość oraz rodziny, obywateli i gospodarstwa domowe, przynosząc oszczędności w okresie pierwszych jedenastu lat (od roku wejścia w życie ustawy):

- dla dużych przedsiębiorstw oraz sektora mikro, małych i średnich przedsiębiorstw - 1196 mln zł (w roku 2019 - 39 mln, w 2020 r. - 113 mln, zaś w każdym z następnych lat - po $116 \mathrm{mln} \mathrm{zl}$ ),

- dla rodzin, obywateli i gospodarstw domowych - 2184 mln zł (w roku 2019 - 70 mln zł, w 2020 r. - 206 mln zł, zaś w każdym z następnych lat po $212 \mathrm{mln} \mathrm{zl})$.

Wyliczenia te nie budzą istotnych zastrzeżeń. Wątpliwości dotyczą strony wydatkowej - kosztów wprowadzenia WIS związane są przede wszystkim z rozszerzeniem katalogu instytucji prawnych mających na celu zapewnienie podatnikom pewności prawa [obecnie funkcjonują już interpretacje podatkowe (ogólna i indywidualna), urzędowe ogólne wyjaśnienia przepisów prawa podatkowego dotyczące stosowania tych przepisów (objaśnienia podatkowe), wiążące informacje akcyzowe, opinie zabezpieczające, porozumienia w sprawach ustalania cen transakcyjnych]. Tego typu regulacje w istotny sposób wpływają na koszty poboru podatków przez organy podatkowe oraz przestrzegania przepisów przez podatników ${ }^{22}$.

22 Zob. Oddzialywanie instytucji interpretacji podatkowych na finanse przedsiębiorstw, red. T. Famulska, Warszawa 2013, oraz J. Kulicki, Ocena skutków wprowadzenia i sto- 
W budżecie państwa na 2019 r. na działalność Krajowej Informacji Skarbowej, która m.in. wydaje interpretacje indywidualne oraz ma zajmować się wydawaniem wiążących informacji stawkowych, przewidziano 82794 tys. zł $^{23}$. Projektowane zmiany mają kosztować dodatkowo budżet państwa ok. 25-28 mln zł rocznie (w 2019 r. - 15,1 mln, w 2020 r. - 25, 2 mln, w 2021 r. - 26,7 mln, w 2022 r. - 27,5 mln zaś w 2029 r. - 27,9 mln). System zabezpieczenia podatników przed skutkami braku spójności i przejrzystości prawa podatkowego ma kosztować więc ponad $100 \mathrm{mln}$ zł (łącznie z wydatkami na WIS), co stanowi ok. 1,7\% wydatków przewidzianych w budżecie państwa na 2019 r. na działalność izb administracji skarbowej ${ }^{24}$. Wydaje się, że koszty te można by było znacznie ograniczyć, gdyby część planowanej kwoty przeznaczyć na poprawę jakości stanowionego prawa podatkowego, która ma zasadnicze znaczenie dla przejrzystości i spójności prawa podatkowego, a co za tym idzie wykonywania tego prawa przez podatników, pewności prawa i kosztów jego przestrzegania.

\section{Podsumowanie - ogólna ocena projektu}

Projekt wprowadza zmiany w ustawie o podatku od towarów i usług oraz Ordynacji podatkowej w zakresie: sposobu identyfikowania towarów i usług dla celów podatku VAT, nowego wykazu (matrycy) preferencyjnych stawek podatku VAT, systemu ryczałtowego dla rolników, wiążącej informacji stawkowej, systemu odwróconego obciążenia i instytucji solidarnej odpowiedzialności.

Zmiana sposobu identyfikowania towarów i usług dla celów podatku VAT, choć znacznie ogranicza liczbę pozycji wykazu towarów i usług objętych stawkami obniżonymi, nie stanowi istotnego uproszczenia systemu podatku od towarów i usług, bowiem w dalszym ciągu będziemy mieli do czynienia z systemem opartym na stosunkowo wysokiej stawce podstawowej (23\%) oraz rozbudowaną strukturę stawek obniżonych, co niewątpliwie wpływa negatywnie na: pewność prawa, koszty poboru podatku oraz koszty przestrzegania przepisów przez podatników.

Konsekwencją podwyższenia stawki na niektóre napoje owocowe może być ograniczenie zapotrzebowania polskiego przemysłu napojowego na owoce i warzywa z polskich upraw, szacowane na 75\%, a w konsekwencji zmiana struktury

sowania instytucji indywidualnych przepisów prawa podatkowego [w:] Wybrane zagadnienia stanowienia i stosowania polskiego prawa podatkowego, red. J. Kulicki, Warszawa 2017, s. 71-117.

23 Zob. ustawę budżetową na rok 2019 z 16 stycznia 2019 r., Dz.U. poz. 198, załącznik 2, cz. 19.

24 W budżecie państwa na 2019 r. na działalność izb administracji skarbowej przewidziano 5805149 tys. zł, natomiast na KIS - 82794 tys. zł, zob. załącznik nr 2 do ustawy budżetowej na 2019 r., cz. 19, rozdz. 75008 i 75024 . 
spożycia napojów bezalkoholowych, pogłębienie się trudności branży owocowo-warzywnej (producentów owoców i przetwórców), prowadzące do upadku wielu gospodarstw ogrodniczych i zakładów przetwórczych, a także pogłębienia bezrobocia na rynkach lokalnych.

Kształtowanie stawek podatkowych ma, obok aspektu prawnego, fiskalnego i gospodarczego, również aspekt społeczny i polityczny, co oznacza, że decyzja o podwyższeniu lub obniżeniu stawki podatkowej musi uwzględniać zarówno prawną (spójność i przejrzystość systemu), fiskalną (wpływ na dochody budżetowe) i gospodarczą (wpływ na przedsiębiorców) stronę, lecz również brać pod uwagę odbiór społeczny proponowanych regulacji oraz uwarunkowania polityczne.

Rozpatrując projektowane zmiany ustawy o podatku od towarów i usług przede wszystkim w zakresie podwyższenia stawek VAT, łatwo zauważyć, że przedstawienie ich $\mathrm{w}$ roku wyborczym może przesłonić inne proponowane regulacje (m.in. skalę obniżek stawek VAT, rozszerzenie zakresu zryczałtowanego systemu podatku VAT od rolników, wprowadzenie wiążącej informacji stawkowej).

Reasumując, opiniowany projekt powinien zostać zwrócony wnioskodawcy w celu uzupełnienia uzasadnienia w odniesieniu do podwyższenia stawek podatku od towarów i usług na niektóre towary, przede wszystkim na napoje owocowe, lub dokonania zmian o charakterze merytorycznym uwzględniającym wcześniej przytaczane argumenty (co wiązałoby się z przedłożeniem autopoprawki do niniejszego projektu).

\section{Bibliografia}

Gomułowicz A., Mączyński D., Podatki i prawo podatkowe, Warszawa 2016.

GUS, Produkcja upraw rolnych i ogrodniczych w 2017 r., Warszawa 2018.

Kulicki J., Ocena skutków wprowadzenia i stosowania instytucji indywidualnych przepisów prawa podatkowego [w:] Wybrane zagadnienia stanowienia i stosowania polskiego prawa podatkowego, red. J. Kulicki, Warszawa 2017, http://dx.doi.org/10.12775/ PBPS.2017.019.

Marchlewski P. [w:] Dyrektywa VAT. Polska perspektywa, red. R. Namysłowski, D. Prokop, Warszawa 2012.

Oddziaływanie instytucji interpretacji podatkowych na finanse przedsiębiorstw, red. T. Famulska, Warszawa 2013. 